\title{
6 \\ The interwoven histories of Mount Liebig and Papunya-Luritja
}

\author{
Sarah Holcombe
}

Mount Liebig, known by Anangu as Amunturrngu and referred to by the regional shire as Watiyawanu, is part of the regional constellation of Pintupi-Luritja settlements that also includes Haasts Bluff, Papunya and at least 16 outstations, the majority of which are still inhabited. ${ }^{1}$ The 2011 census recorded Mount Liebig with a population of 156 people, ${ }^{2}$ while the Mount Liebig and Outstations Quickstats showed a slightly higher population of 184 people. ${ }^{3}$ Note that both of these figures also include non-Indigenous people. Mount Liebig - though now regarded as a 'state suburb' for the purposes of the census - itself began as an outstation. This chapter will trace the emergence of this place as it became the focus of both Pintupi-Luritja sentiment and respite from the earlier days of Haasts Bluff and the later coercive assimilationist vision of Papunya. That its relatively informal and incremental development into a substantial settlement has been led by Anangu, rather than the state, also has implications for the ways in which the place has emerged as a community, rather than merely a settlement. Unlike Papunya, which has been described as 'mixed up', Mount Liebig has

\footnotetext{
1 Anangu is the Western Desert term for person, Pintupi-Luritja being a Western Desert language, on the north-eastern edge.

2 That is: 69 male, 87 female, with a median age of 31. See the Australian Bureau of Statistics (ABS) QuickStats website: www.censusdata.abs.gov.au/census_services/getproduct/census/2011/quickstat/SSC7013 5 ?opendocument \&navpos $=220$

3 Average people per household: 4.6.
} 
an internal coherence that was led by succession processes and subsequent re-territorialisation. The reconfiguring of people at this place has been enabled by the new Indigenous language of Pintupi-Luritja; residents who chose to remain after the 1980s actively identified with this new language, referred to by linguists as a communilect. By foregrounding endogenous political processes, this essay conceptualises self-determination as a process in relation to other Aboriginal people as well as in relation to the State. The emergence of the Luritja language in this region, and its consolidation at Mount Liebig and surrounding outstations, was an expression of the need to regroup and reformulate a local identity after unprecedented historical interventions.

\section{From stock bore to community}

Mount Liebig Bore was a camp in the days when Haasts Bluff was a ration station for Aboriginal people west of Hermannsburg in the 1940s. Many of the people who had early come in to the Lutheran ration depot used it only as a convenience; they traded dingo scalps for food and returned to the bush. There is a series of permanent springs west of Haasts Bluff in the Amunturrngu and Kartilka ranges that makes for plenty of bush foods, even in the dry. The springs of Amunturrngu, Impimpi, Arlkngilkinti, Irantji, Putati and the numerous semi-permanent waters and rockholes were places for 'holiday camps' and remain so for many community members today. These waters gave people the autonomy to live without any absolute reliance on rations and supported a series of families. Many of these families were originally enticed into the area by the Hermannsburg missionaries, from the period of the establishment of Hermannsburg in 1877 through to the establishment of Haasts Bluff in 1941 and the few ration depots at surrounding springs (see Long 1989: 22-3).

Mount Liebig first became an 'official' outstation service centre in 1982, when the Central Desert Store was established. It provided a convenient location for provisioning the surrounding outstations of Warren Creek, New Bore and Inyilingi. The original Mount Liebig Bore was sunk as a stock bore in 1946, followed by Warren Creek, also as a stock bore, in 1961. Nearby Inyilingi Bore was sunk in 1975 and New Bore in 1980, both as community-purpose bores to encourage the Pintupi movement west, homewards, from Papunya. Kakali Bore, originally sunk for the Haasts Bluff cattle project but then the foundation for the Yayayi outstation, was the first of these community-purpose bores and the closest to Papunya. Unlike these others, however, Yayayi was not further consolidated as an outstation, and other than the derelict bore by the main eastwest road, no other infrastructure remains (see Myers, this volume). 
Mount Liebig, and later Inyilingi, was originally conceived in terms of the government policy of encouraging the Pintupi to shift away from Papunya, where life was proving so traumatic for them, and the Pintupi themselves were keen to move westward in the direction of their country. In Papunya, there was conflict between the more latterly arrived Pintupi and the more established Luritja and Warlpiri. Kimber sums up the sentiment surrounding this policy era in the region: the assimilation '[p]olicy and its implementation both west of Papunya and at Papunya can best be summarised as a white disaster, an Aboriginal tragedy' (1981: 23). There were a significant number of deaths among the newly arrived Pintupi, many of which were blamed on sorcery and related antagonisms (cf. Myers 1976; Kimber 1981). The official medical point of view was that 'more disastrous (than fighting and adjustment to rations) were the infections, largely pneumonia or viral (measles), that destroyed more than half the population, which came with low levels of immunity to close contact with reservoirs of disease' (Kimber 1981: 26). Of the 72 people who came into Papunya in 1963 and 1964, 29 had died by August 1964 (Nathan and Japanangka 1983: 79-80).

With this high mortality rate, questions were raised in Parliament. This led to an unofficial policy change in 1964, so that centralisation was replaced with dispersal (Nathan and Japanangka 1983: 79-80). However, as Long notes, this policy was not activated until the late 1960s and early 1970s. This delay was due to the centralised focus of the food disbursement, among other things. In Papunya, Aborigines who wanted to eat had to attend the communal dining room - 'because it made it easier to organise and to supervise the settlement work programs' (Kimber 1981: 24; and see Myers, this volume). The, at times, militaristic demands made on people to 'learn European manners' caused newly arrived people to be ridiculed by both insensitive white staff and the more sophisticated Aboriginal people, primarily the Luritja. Kimber states that 'I have been told that almost the entirety of one newly arrived Pintupi group were made to feel so ashamed that they stayed away or refused to eat' (1981: 24).

The Pintupi were thus keen to establish their own outstation/community that was not only closer to their country, but was also independent of the strictures of settlement life and these other groups, with Yayayi outstation the first formal expression of government support for this. And with the sinking of the Ilypili Bore in the Ehrenburg Range and soon after the series of Kintore bores, the Pintupi continued the move west via Mount Liebig to their own country, establishing Warlungurru (Kintore) as a community in the early 1980s. 


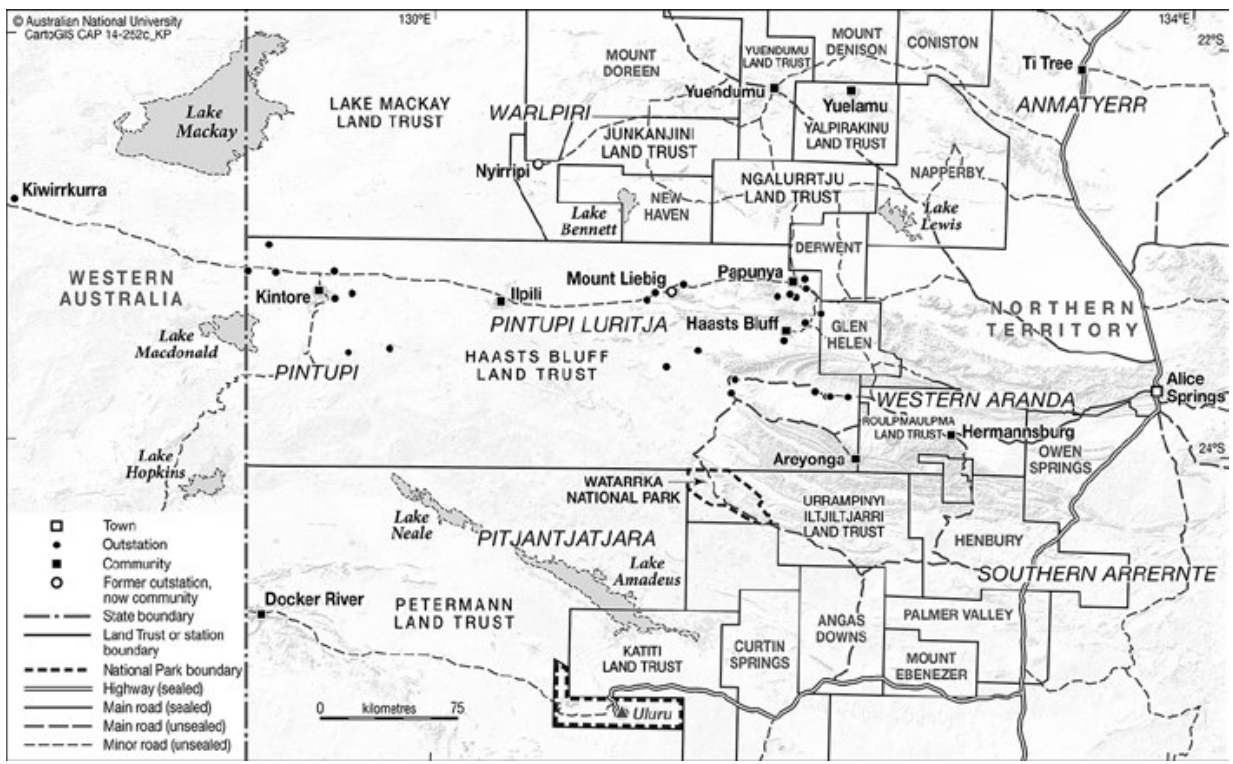

\section{Map 6.1 Luritja-Pintupi outstations.}

Source: Karina Pelling, CartoGIS, ANU College of Asia and the Pacific

Nathan and Japanangka state:

[The Luritja] people reoccupied the [Mount Liebig] site [from the Pintupi] in 1981. There were 39 people comprising 17 women, 4 men and 18 children. Some of the men were absent because they were engaged in stock-work elsewhere ... there are 12 temporary shelters including bough shades and half tanks turned upside down ... there is one tap about 120 metres from the main camp site. The camp is provided with a radio. There is no council truck but a number of private vehicles, some of which are broken down. A health worker and an Aboriginal assistant for the mobile school are employed. The school which operates on a four day a week basis, consists of a shady tree and a quarter moon shaped corrugated iron windbreak. Today, there is no evidence of the temporary resource Centre which was built in 1979. This Centre was to have been used as a store and garage, and to house horticultural equipment. (Nathan and Japanangka 1982: 132)

Although it seems that the early service provisions at Mount Liebig were originally established for the Pintupi, the Luritja did not suddenly reoccupy the site when the Pintupi left in 1981, as suggested above. The Luritja who were recorded there in 1981 had also been intermittent residents, but more long term than the Pintupi. They had been mustering cattle in the area since the 1950s, making use of the Mount Liebig and Warren Creek stockyards. Cattle were herded south to Haasts Bluff through Berry Pass and Irantji Spring. Others, who were elderly when I interviewed them in the mid-1990s, were recorded at Putati and Mount Liebig during the 1932 joint Adelaide University and South Australian Museum expedition (Holcombe 1998). However, in 1981, Mount Liebig became a family 
outstation similar in size to the surrounding outstations, after the Pintupi left to return to their country. And it was then that the small Central Desert Store was established. It became an Aboriginal corporation in August 1988 and effectively a major settlement, attracting several other Luritja families from Papunya.

This expansion brought with it increased services. Today, these include a school, clinic, store, the council (now shire) office, an aged care centre, a preschool, a Lutheran church and approximately 30 Aboriginal houses and six nonAboriginal service-worker houses. More recently, a large demountable complex was also established for the temporary influx of service provider staff from the various government agencies after the 2007 NT Emergency Response (NTER). ${ }^{4}$ While the NTER set of legislation and policies was an unequivocal rejection of self-determination, as it ushered in the current neo-assimilationist era, the years during which I undertook field research in the mid-1990s were the final ones of the official policy of self-determination and a period of considerable autonomy for Anangu. Engagement with the apparatus of the state, such as the education and employment systems, was not mandated. Indeed, it has been noted during this period that there was a structural disengagement by government (Dillon and Westbury 2007), not only in Mount Liebig but also across remote communities. So while, on the one hand, there were very active customary and ritual economies practised at Mount Liebig and surrounding outstations, there were also significant social issues with youth petrol sniffing in this region, as in other Western Desert communities. Thus, this government disengagement at that time, while extremely positive in some ways, also impacted as limited recognition of the emergence of the petrol-sniffing problem (see Brady 1992). Indeed, researchers like myself were also unaware of the scale and long-term debilitating effects of the petrol sniffing at that time.

\section{Early 'contact' and movement towards settlement}

The pattern of movement for the majority of middle-aged and elderly members of the Mount Liebig community, almost without exception, has been from Haasts Bluff to Papunya and finally to Mount Liebig or surrounding outstations. Their parents and several elderly women and men who only passed away within the past 10 years first migrated to the settlement of Haasts Bluff in the early 1940s. Many of the people who initially moved to the settlement had been

4 The NTER was a suite of measures implemented through legislation and policy designed to run for five years to 'stabilise and normalise' remote NT communities on Aboriginal land and in town camps. It included strongly interventionist measures to ensure that parents sent their children to school, welfare reforms, income quarantining and increased policing levels (see Altman and Hinkson 2007). 
living in the outlying areas. On an annual visit in 1936 from Hermannsburg, Pastor Friedrich Albrecht estimated that his party had contacted groups totalling nearly 300 people in the area between Haasts Bluff, Mount Wedge and Mount Liebig (Long 1989: 21). The rationale for establishing the Haasts Bluff settlement was government concern over the eastward drift of 'western people' towards Alice Springs and, in particular, towards pastoral leases such as Glen Helen and Tempe Downs. These western people were, at this stage, the Eastern Pintupi and the Ngaliya Warlpiri.

In the period from 1930 to 1932, the eastern reaches of Pintupi country had been visited by several prospecting parties and missionaries and probably by a police party - more visitors than in the preceding 60 years since explorer Ernest Giles first reached the Ehrenburg Range (known by Anangu as Ilypili) from a spring within the range (Long 1989: 29). As the Pintupi and Ngaliya from Ilypili had moved east, by 1942 a wide expanse of uninhabited country had opened up between Haasts Bluff/Mount Liebig and the WA border. This not only had implications for those Anangu who remained further west, as they were growing increasingly isolated, but it also reflected a broader pattern of migration and a demographic pulsing (see below).

It seems that as these western and northern peoples were travelling east, those who were principally affiliated with the country affected by this migration had themselves migrated east and south considerably earlier. Long indicates that by the time the Haasts Bluff settlement was established, the Aboriginal population of the area proper had 'largely disappeared ... having died out or become absorbed into the population of ... Hermannsburg ... and other places to the east' (1970: 321). While there are historical disagreements and elements of conjecture about who these peoples were, the language labels of Mayutjarra and Kukatja were provided to me in the mid-1990s by elderly residents of Mount Liebig, while the Lutheran linguist John Heffernan also recorded these names for the same area. Although some of us find this movement of language frontiers intrinsically interesting - and I have written about this history in detail elsewhere (Holcombe 1998, 2005) - the point to be made here is the correlation between the emergence of the communilect of Pintupi-Luritja, the succession to this land and the consolidation of Mount Liebig as an articulation of self-determination. This self-determination was in relation to both other Aboriginal and non-Aboriginal people. Thus, it was an attempt to reform the internal relations of the Aboriginal polity, to return it to the land/people relationships that were either 'traditional' or idealised as such. This reconstitution or reclamation of an Aboriginal polity was just as relevant a discursive act in the decentralisation process as the desire to live independently of government interference and control. 
Pintupi-Luritja is categorised as a communilect, rather than a dialect, according to Heffernan (1984). This is because the language developed as a lingua franca for the various family groups who first moved to Haasts Bluff in the 1940s who spoke various languages, such as Western Desert 'multi-group dialects' ${ }^{5}$ that are now conflated as Pintupi, various Arandic dialects, Warlpiri dialects such as Ngaliya, and Anmayterr - especially after the massacre of Aboriginal families at Coniston Station, as people fled south. ${ }^{6}$ Because the language first emerged in these communities, linguists originally referred it to as Papunya-Luritja. So although this is an Indigenous language, it is not a pre-settlement language. It also has different features to the Luritja that is spoken from Areyonga south to Finke and Oodnadatta. However, as the Mount Liebig and Papunya residents refer to their language simply as 'Luritja', I also will from now on.

\section{Luritja as a process of re-territorialisation}

The Mount Liebig community and outstation members identify themselves as Luritja and the country they are living on as Luritja country. The configuration of people in this community and the identity they share today developed as a result of movement towards settlement. They came together primarily from neighbouring areas on to country that had been apparently 'vacated'. They adopted this country, the country of the Mayutjarra, and its name, Amunturrngu. The dynamics of re-territorialisation are considered in the light of this history. The term 'Luritja' can usefully be interpreted as a trope. The meaning of the original word is not only indicative of the regional history, it also signals the value of the term in contemporary usage, as I will discuss. ${ }^{7}$

As the history and pattern of movement indicate, the country within which the communities of Haasts Bluff, Papunya and Mount Liebig are today situated became the focus of several groups as they moved towards settlement. But as these groups were more or less neighbours, how discrete as 'groups' were they? Tindale recorded that the 'Pintupi made their first modern contact with the Jumu [Yumu] and Ngaliya in 1932 ... at Mount Liebig where they were studied' (1974: 138). It seems unlikely, however, that they had not encountered each other before this. ${ }^{8}$ Heffernan (1984: 2) indicates that in pre-contact days the Ilypili

\footnotetext{
5 See Ken Hansen (1984) for a discussion of the Western Desert 'multi-group' dialects.

6 Occurring in 1928, this massacre claimed the lives of between 17 (the 'official toll') (Cribben 1984: 75), 31 (the number the board of inquiry found) and 100 Aboriginal men, women and children, depending on which texts are consulted. Fred Brooks, the non-Aboriginal dingo hunter who was killed by Aboriginal people, would never have been at the same soak with the group of Ngalia Warlpiri if mutual desperation for water and the Aboriginal need for non-native foods had not been high. The massacre, led by police, was an official reprisal party.

7 See also Holcombe (2004a) for further analysis.

8 Note that Mackay recorded both Pintupi and Yumu living at Ilypili Spring in 1930.
} 
people intermarried with the Ngaliya Warlpiri from Kunatjarrayi, a significant Ngaliya site to the north of Ilypili. Almost without exception, the descendants from the Ilypili people are both of "Pintupi" and "Warlpiri" parentage. ${ }^{9} \mathrm{He}$ also found that the eastern neighbours of the Pintupi are the Mayutjarra (Kukatja). Like myself, Heffernan appears to have found no evidence of the 'Yumu', the name that Tindale gave to the peoples of the Mount Liebig, Haasts Bluff and Papunya region.

So Luritja identity is an articulation of the shared heritage of the otherwise disparate people who moved east and south and remained. So why Luritja, and not some other language appellation? The term 'Luritja' is itself a derivative of a general term for Western Desert people. Strehlow indicates that:

Loritja [Luritja] is the name applied by the Aranda to all Western Desert speech groups. Loritja languages are spoken from the Western MacDonnells to Mount Margaret, in Western Australia, and from the Granites in the north to Ooldea on the Trans-continental railway. None of these Western groups speak of themselves as 'Loritja'. They call themselves Kukatja, Pintupi, Ngalia, Ilpara, Andekerinja, etc. (Strehlow 1947: 177-8)

Tindale emphasised that the name Luritja was considered derogatory and that Strehlow referred to the Kukatja from the Arrernte perspective. He stated that 'in 1929 [he] was asked by the old men of this tribe to refrain from using the term imposed on them by the [Arrernte] and to record their "true" name-Kukatja" (Tindale 1974: 229). And understandably so, given that the term was an insult. Strehlow (1947: 52) indicates that the term Luritja is 'suggestive of everything that is barbarian, crude, savage and generally speaking non-Aranda'. ${ }^{10}$ This Arrernte ethnocentrism was earlier recorded by Elkin, who noted that 'Loritja is an Aranda word meaning stranger' (1938: 424, in Doohan 1992: 36). Thus, historically, the term was not self-definitional.

However, over the settlement period in Haasts Bluff and Papunya, the meaning of the term Luritja shifted dramatically. It was the dynamic of this period through which the Luritja became self-identified as a group in terms of language and predisposition. This identification was, of course, oppositional, in relation to non-Luritja. Heffernan (1984: 3) 'guesses' that the wholehearted adoption of the term Luritja was not made until the most recent arrivals from the desert

\footnotetext{
9 According to my 'informants', Ilypili formed the eastern boundary of the Pintupi. Interestingly, Heffernan has the eastern neighbours of the Pintupi as the Kukatja/Mayutjarra, rather than the Luritja. He has also suggested that 'Papunya Luritja could in fact be a true description of the Eastern Pintupi dialect as it existed prior to European contact. Whereas this is partly true there is good evidence from text material to show that speakers east of Warlungurru [where the Kintore community is situated] spoke much the same as the description given by Hansen and Hansen [for Warlungurru or Western Pintupi]' (Heffernan 1984: 3). 10 In fact, Strehlow wrote this in relation to a statement made by a Northern Arrernte man, who referred to the Western Arrernte as 'half-breed Loritja'.
} 
occurred in the late 1950s and early 1960s - a perspective also supported by the linguists Hansen and Hansen (1978). It was initially this construction of difference between the Luritja as the people 'from the east', in relation to the (western) Pintupi, that contributed to Luritja becoming a positive group label. Those who had been in the settlements the longest and had become accustomed to the new ways of interacting in this context were differentiating themselves from those newly arrived from the west. This distinction between newcomers and residents, notably in Papunya, became so marked that to be called 'Pintupi' was an insult, like the term Luritja before it. This term was comparable with the poor country cousins, the unsophisticated. Clearly government policy during the Papunya period played a key role in ostracising the Pintupi, so that the adoption of the term Luritja is deeply implicated in this period of assimilation. As Myers notes in his chapter in this volume, the latterly arriving Pintupi with whom he worked at Yayayi were determined to leave the 'illness, morbidity, conflict and depression' of Papunya.

Earlier I noted:

The adoption of the Luritja language is an implicit rejection of the multiple genealogies represented in the communities, as expressed in the languages of the previous generation. The language of Luritja, contemporary as it is, places the past in abeyance (cf Jackson 1996). As a communilect, Luritja is representative of what Clastres defines as a people without history, a people concerned more with today than yesterday. By emplacing the individual speaker, the term holds within it an identity that conjures up the surrounding land and its settlement history. (Holcombe 2004a: 267)

Although being a member of a speech community is relative, as being a member of any group is relational, it is the element of choice that informs a political position. For instance, the now deceased Ginger Tjakamarra of New Bore outstation, one of Fred Myers' informants, was during Myers' fieldwork identifying as Pintupi (Myers 1986: 8, 264). When I conducted my field research some 20 years later, Tjakamarra and his family from New Bore identified as Luritja. After living on this outstation on Luritja country for more than 20 years, this long-term post-migration residence has encouraged a shift towards an identity that marks not only a shared history, but also a distinctive label that tells of the need for grosser, community-based distinctions. ${ }^{11}$ Likewise, Whisky Tjapaltjarri (also recently deceased), the male head of the family from Yinyilingki outstation, was historically Pitjantjatjara. However, after a comparable history of long-term residence and the conception of children and grandchildren at the outstation, a reconfiguration of social identity emerged. Likewise, these two

11 This lability of identification also speaks of the context and historical moment in which the researcher is operating. 
men, along with their spouses and residential classificatory female kin, have been especially active in the performance of inma kuwaritja (new ritual derived from dreams) that situates them sentimentally and politically within the landscape of their residence (Holcombe 2004b: 267).

Although not all Luritja are landholders, there is a correlation between language territory and land ownership. The pulsating heart analogy offered by Sutton is useful here, as it connotes the propensity of a people to fill a void - perhaps akin to a type of human osmosis - in the drive to reach a demographic equilibrium (see Sutton 1990: 74). This striving towards integration, out of possible disintegration, is invoked in this history of movement from the west that many now deceased, elderly Luritja in Mount Liebig spoke of when questioned. This migration to the better-watered country of the relatively fecund fringes of the West MacDonnell Ranges could be understood as part of the general tendency of desert dwellers towards expansionism and opportunism, given the ecological constraints of the area (see Hamilton 1982: 103; Peterson 1975 Sutton 1990). The logical progression of this line of argument suggests that when constraints are lifted, when the environmental limitations on food and water are radically diminished by the new welfare apparatus then so too are there possibilities to 'stabilise' local organisation. I found such stability in the land tenure of Mount Liebig during the mid-1990s where the concept of re-territorialisation was appropriate. ${ }^{12}$ This concept evoked the processes of succession or 'tenurial migration', to borrow Sutton's (1997) term, as well as the imaginative processes that are involved in long-term post-migration residence. The term 're-territorialisation' offers a more generous and less hierarchical approach than that of the concepts of primary and secondary succession (per Peterson) when considering community member attachment to the community country. Clearly, this is a big topic; what I can say here is that for Mount Liebig, the constellation of the social technologies such as the 'company relationship' for Dreamings and social groupings - as these were locally long term and included the site of conception - was such that succession processes were fairly seamless and relatively un-politicised. This was not the case in Papunya.

Tod Woenne (1977: 56) indicates that the 'self-conscious reconstruction and assertion of local pre-settlement conditions was a conspicuous and much engaged in activity at Docker River in the early years of its establishment', in 1968. The situation in Mount Liebig has differed from this in that it is the reconstruction of early settlement conditions that is a primary means through which people negotiated affiliation rights in Mount Liebig in the mid-1990s. Those Luritja families who first established themselves at the Mount Liebig

12 I am not using this term here in the manner of Deleuze and Guattari (1987), although their employment of this term (and its opposite) also has clear implications in geopolitical terms. 
Bore became the definable core of the community. The families who arrived in the late 1980s, after the increased services, also had a right to settle on the basis not only of identifying as Luritja, but also of sharing a history of holiday camping in the Mount Liebig area as far back as the Haasts Bluff days, the 1940s. As these immigrants to this land have remained, deep attachments have formed. Their knowing of the land, by travelling over it, utilising its resources and learning its law, has translated into various forms of 'ownership'. This 'ownership' can only be considered in terms of the 'emplacement' of the community members and the processes whereby they have become locals. The land of the community is, in many respects, the land of their learning.

The rights of residents are, however, based not only on this shared settlement history. There are a number of other factors - some alluded to earlier. There is, for example, the question of what the impetus was for the second major wave of migration from Papunya. An 'original' resident, the now-deceased Maudie Nungurrayi, phrased it as 'they only came after the store. We lived here with nothing.' Maudie consistently stressed the role that she and her family played in establishing the community. They created a resource base that then allowed others to move there in numbers. Her emphasis on the community as a recently built environment is contrasted with the days when there was 'nothing' - only the bore, bullocks and bush. This contrast can be read as suggesting that the establishment of locality begins with dwelling; the stress is on the place prior to its occupation as a resource centre. Thus, the recent influx of others - after the resource allocation - is perceived as having less legitimacy. Yet, it was after this provision of resources that the place gained permanence and a sense of recognition. Heidegger's notion of 'gathering' and the construction of location through building and therefore 'dwelling' is relevant to perceptions of the built community, as opposed to the pre-community bush. ${ }^{13}$

So a major incentive for the new residents was increased access to services and, concomitantly, less competition for these services, relative to Papunya. The ways in which these families negotiated access to resources, such as houses and store profits (from which vehicles were purchased), offered a lens, during this late period of self-determination, through which to view processes of community membership (see Holcombe 2005).

13 Heidegger's focus, however, is European and accordingly the notion of people without dwellingssuch as in pre-contact Aboriginal culture - is not considered. As a result, his argument is relevant to change and the creation of locations of permanence, yet the subtleties of considering the construction of locations through the imagination (as in the case of the tjukurrpa, Dreaming) seems to elude him (cf. Heidegger 1978). 


\section{Conclusion}

My research focus in the mid-1990s was on the various mechanisms that crafted a community from a settlement and the ways in which this 'community' was the medium through which contemporary forms of cultural authenticity were constructed, and so how the 'Aboriginal power of imagination' (Stanner 1966: 52) was brought to bear on this new home. In doing this, Mount Liebig was understood in terms that specified its power to direct and stabilise its residents, 'to memorialise and identify [them] by considering who and what [they] are in terms of where they are' (Casey 1993: Preface). As Geertz (1983) and Casey (1996) have both noted: to live is to live locally and to know is first of all to know the place one is in. The cultural imagination in Mount Liebig derived from the stimulus of Amunturrngu as a location that has been doubly colonised in recent history: by non-Aboriginals, followed by neighbouring Aboriginal groups. The fact that the country was apparently vacant enabled this reimagining of various forms of ownership, which the communilect of Pintupi-Luritja effectively facilitated. Self-determination in this context applies as much to the endogenous processes of re-establishing an Aboriginal polity as it does to escaping the grip of the colonial masters through decentralisation. Mount Liebig and neighbouring outstations were expressions of reformulated social groupings after the enforced settlement of Papunya. This period, in the mid-1990s, was one in which Anangu in Mount Liebig practised considerable autonomy from the state. The neighbouring outstations were all active, and while cultural activity (such as hunting and ceremony) were thriving, petrol sniffing was also a significant emerging issue that took another 20 years to be brought under control in Central Australia (see d'Abbs and MacLean 2011).

\section{References}

Altman, J. C. and Hinkson, M. (eds) 2007. Coercive Reconciliation: Stabilise, Normalise and Exit Aboriginal Australia. Melbourne: Arena Publications.

Brady, M. 1992. Heavy Metal: The Social Meaning of Petrol Sniffing in Australia. Canberra: Aboriginal Studies Press.

Casey, E. S. 1993. Getting Back into Place: Toward a Renewed Understanding of the Place-World. Bloomington \& Indianapolis: Indiana University Press,

Casey, E. S. 1996. How to get from space to place in a fairly short stretch of time: Phenonemological prolegomena. In S. Feld and K. H. Basso (eds), Senses of Place. Santa Fe, NM: School of American Research Press, pp. 13-52. 
Clastres, P. 1987 [1974]. Society against the State. New York: Zone Books.

Cribben, J. 1984. The Killing Times: The Coniston Massacre 1928. Sydney: Fontana Books.

d'Abbs, P. and MacLean, S. 2011. Petrol sniffing interventions among Australian Indigenous communities through product substitution: From skunk juice to Opal. Substance Use and Misuse 46: 99-106.

Deleuze, G. and Guattari, F. 1987. A Thousand Plateaus: Capitalism and Schizophrenia. B. Massumi trans. New York: Continuum.

Dillon, M. C. and Westbury, N. D. 2007. Beyond Humbug: Transforming Government Engagement with Indigenous Australia. Adelaide: Seaview Press.

Doohan, K. 1992. One Family, Different Country. Oceania Monograph 42. Sydney: University of Sydney.

Geertz, C. 1983. Local Knowledge: Further Essays in Interpretive Anthropology. New York: Basic Books.

Hamilton, A. 1982. Descended from father, belonging to country: Rights to land in the Australian Western Desert. In E. Leacock and R. Lee (eds), Politics and History in Australian Band Societies. Cambridge: Cambridge University Press, pp. 85-108.

Hansen, K. C. 1984. Communicability of some Western Desert communilects. In J. Hudson and N. Pym (eds), Language survey. Work Papers of SIL-AAB, Series B, Vol. 11. Darwin: Summer Institute of Linguistics, Australian Studies Branch.

Hansen, K. C. and Hansen, L. 1978. The Core of Pintupi Grammar. Alice Springs, NT: Summer Institute of Linguistics, Australian Aborigines Branch.

Heffernan, J. A. 1984. Papunya Luritja Language Notes. Papunya, NT: Papunya Literature Production Centre.

Heidegger, M. 1978. Basic Writings: From 'Being and Time' (1927) to 'The Task of Thinking' (1964). London: Routledge \& Kegan Paul.

Holcombe, S. 1998. Amunturrgu: An emergent community in Central Australia. Unpublished PhD thesis. University of Newcastle, NSW.

Holcombe, S. 2004a. The politico-historical construction of the Pintupi-Luritja and the concept of tribe. Oceania 74(4): 257-75. 
Holcombe, S. 2004b. The sentimental community: A site of belonging. A case study from Central Australia. The Australian Journal of Anthropology 15(2): 163-84.

Holcombe, S. 2005. Luritja management of the state. In M. Hinkson and B. Smith (eds), Figuring the intercultural in Aboriginal Australia. Oceania 75(3): 222-33.

Jackson, M. 1996. Introduction: Phenomenology, radical empricism, and anthropological critique. In M. Jackson (ed.), Things As They Are: New Directions in Phenomenological Anthropology. Bloomington and Indianapolis: Indiana University Press, pp. 1-50.

Kimber, R. G. 1981. The Pintupi of the Kintore Range. Unpublished report for the Department of Aboriginal Affairs.

Long, J. 1970. Change in an Aboriginal community in Central Australia. In A. R. Pilling and R. A. Waterman (eds), Diprotodon to Detribalisation: Studies of Change among Australian Aborigines. East Lansing, Mich.: Michigan State University Press, pp. 318-32.

Long, J. 1971. Arid region Aborigines: The Pintupi. In D. J Mulvaney and J. Golson (eds), Aboriginal Man and Environment in Australia. Canberra: The Australian National University Press, pp. 262-70.

Long, J. 1989. Leaving the desert: Actors and sufferers in the Aboriginal exodus from the Western Desert. Aboriginal History 13(1): 9-43.

Myers, F. 1976. To have and to hold: A study of persistence and change in Pintupi social life. PhD thesis. Bryn Mawr College, Pennsylvania.

Myers, F. 1986. Pintupi Country, Pintupi Self: Sentiment, Place and Politics among Western Desert Aborigines. Washington, DC and Canberra: Smithsonian Institution Press \& Australian Institute of Aboriginal Studies.

Nathan, P. and Leichleitner Japanangka, D. 1983. Settle Down Country: Pmere Arlaltyewele. Alice Springs, NT, and Melbourne: Central Australian Aboriginal Congress and Kibble Books.

Peterson, N. 1975. Hunter-gatherer territorality: The perspective from Australia. American Anthropologist 77: 53-61.

Stanner, W. E. H. 1966. On Aboriginal Religion. Oceania Monograph 11. Sydney: Sydney University Press.

Strehlow, T. G. H. 1947. Aranda Traditions. Melbourne: Melbourne University Press. 
Sutton, P. 1990. The pulsating heart: Large scale cultural and demographic processes in Aboriginal Australia. In B. Meehan and N. White (eds), HunterGatherer Demography: Past and Present. Oceania Monograph 39. Sydney: Sydney University Press, pp. 71-80.

Sutton, P. 1997. University of Adelaide Summer School notes on Aboriginal land tenure. Unpublished ms.

Tindale, N. B. 1932. Journal of a visit to Mt. Liebig, Central Australia. August 1932. Unpublished ms, South Australian Museum, Adelaide.

Tindale, N. B. 1974. Aboriginal Tribes of Australia: Their Terrain, Environmental Controls, Distribution, Limits, and Proper Names. Canberra: The Australian National University Press.

Tod Woenne, S. 1977. Old country, new territory: Some implications of the settlement process. In R. M. Berndt (ed.), Aborigines and Change: Australia in the '70s. Canberra: Australian Institute of Aboriginal Studies, pp. 54-64. 
This text is taken from Experiments in self-determination: Histories of the outstation movement in Australia, edited by Nicolas Peterson and Fred Myers, published 2016 by ANU Press, The Australian National University, Canberra, Australia. 